\title{
Medea Revisited: Marina Carr's By the Bog of Cats... and the Modern Defiant Mother
}

\author{
Jinan Waheed Jassim, Ph.D \\ Mustansiriyah University \\ College of Arts \\ Department of English Language and Literature
}

Abstract;

Marina Carr, one of the prominent Irish feminist playwrights, deviates from the mainstream patriarchal portrayal of women in her modern plays. She moves away from the stereotypical image of Irish mother as an emblem of the nation and the land, hence, seen as a selfless, loving, sacrificing woman who identifies herself with the motherhood. Instead Carr introduces broken, maltreated, and defiant women to the modern Irish stage. Her adaptation of the myth of Medea for her play By the Bog of Cats... is considered as a challenge to the classical Greek and Irish drama. Both Medea and Hester Swane are outsiders, betrayed by husbands, outcast from their homeland and community. Their search for identity and independence lead them to commit unspeakable actions. Yet, while Medea was driven by her desire to revenge on a betraying husband, Hester reacted to ongoing fear of abandonment and loss. This paper highlights Carr's talent in portraying modern ordinary mothers who defy the maledominated society and seek a social status in her own right. Mothers who show an untraditional love for their children; a mother who are ready to sacrifice herself for the welfare of her daughter, saving her from a bleak future with a selfish father, dysfunctional grandmother, and immature step mother. Thus, Hester Swane represents new unconventional Irish mother who is willing to defy the norms to prove herself.

Key words: Marina Carr, Medea, patriarchy, modern Irish drama

انحرفت مارينا كار ، إحدى أبرز المسرحيين الأيرلنديين المدافعين عن حقوق المرأة ، عن الصورة الرجولية السائدة للنساء في مسرحياتما الحديثة. وابتعدت عن الصورة النمطية للأم الأيرلندية بعدها شعارًا للأمة والأرض ، فضلا عن أثها مثالا لنكران الذات والمحبة والتضحية والتي تعرف نفسها بدورها كأم. وبدلاً من ذلك ، تقدم كار إلى المسرح الأيرلندي الحديث النساء المكسورات اللواتي يتعرضن لسوء المعاملة واللواتي يتحدين المجتمع. يعتبر استخدام كار لأسطورة ميديا في مسرحيتها "مستنقع القطط" تحديا لكل من الدراما الإغريقية والايرلندية الكلاسيكية. كل من ميديا وهيستر غريبتان ، تعرضتا للخيانة من قبل الأزواج ،

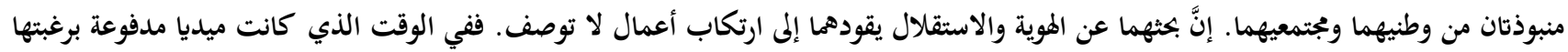
إلى الانتقام من زوج خائن ، كان رد فعل هيستر هو الحوف المستمر من الهجر والحخسارة. تسلط هذه الورقة البحثية الضوء على موهبة كار في تصوير الأمهات العاديات الحديثات اللواتي يتحدين الججتمع الذي يهيمن عليه الذكور ويسعين للحصول على وضع اجتماعي يستحقنه. الأمهات اللواتي يظهرن حبًا

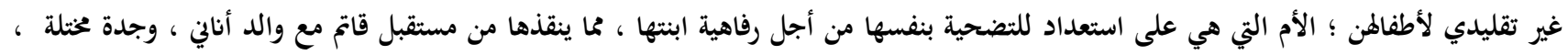
وزوجة أب غير ناضجة. وهكذا ، تمثل هيستر سوين أمًا أيرلندية جديدة غير تقليدية مستعدة لتحدي الأعراف لإثبات نفسها.

$$
\text { الكلمات الرئيسية: ماريناكار ، ميديا ، المجتمع الدكوري ، المسرح الأيرلندي الحلديث }
$$

Marina Carr's play By the Bog of Cats was premiered October 1998 at Abbey Theatre in Dublin (Billington, The Guardian). The play takes place in a bogland in Ireland in an undefined time in the modern era. It contains many mythical and mystical elements, including apparitions, curses, and allusions to witchcraft. It covers issues like betrayal, land 
ownership, ethnic prejudice, abandonment, and motherhood.

The mother, in Irish culture, is a powerful figure. Traditionally, she was used in literature to represent Mother Ireland. She is the symbol of the nation, and the struggle for independence, also she sympolises the religious devotions that were closely connected to notions of patriotism and nationalism. As Lisa Fitzpatrick emphasizes that:

The figure of the mother on the Irish stage is at the centre of a set of cultural and social debates about the roles and experiences of Irish women. This extends from the representation of women as symbols of the nation and as the mothers of patriots, to grieving mothers in times of war, through contemporary feminist debates about intergenerational relationships between daughters and their mothers. This primal and primary relationship continues to be at the centre of Irish drama, telling stories from the perspectives of both mother and child. (2018)

J. M. Synge in his famous play Riders to the Sea (1904) tells the story of an elderly Irish mother, Maurya, who loses her four sons to the sea and waiting for the corpse of the fifth one to be washed out, and predicting the death of the sixth one. She shows a great bravery and endurance defying the sea that took everyone dear to her including her husband and father-inlaw. "What more can we want than that? No man at all can be living for ever, and we must be satisfied." (Synge, 106) Sanford Sternlicht proclaims that this old woman stands for 'allsuffering Irish mothers in modern Irish drama" (71).

In "The Mother", a poem by Patrick Henry Pearse, an Irish mother expresses her contradictory feelings of pride and sorrow about the sacrifice of her two sons who joined war willingly to serve their country, the poem refers to both Mary's sacrifice of her son Jesus Christ and the Irish tradition of the Sean Bhean Bhocht ("Poor Old Woman") that goes back to the Irish Rebellion in 1798. The legend personified in the song of the "Sean Bhean Bhocht" was brought to stage in 1902 play Cathleen $N_{i}$ Houlihan by Lady Augusta Gregory and W.B.Yeats. Pearse's lines, concerning the heroic sons, "they shall be spoken of among their people, the generations shall remember them," (Ryschka 141) resonate a passage in this play; Cathleen, who is proud of the sacrifice of the young sons who are willing to fight and die to save her, says "they shall be speaking forever, the people shall hear them forever"(Richman 32).

Sean O'Casey portrays mother figures who are tough yet resilient, devoted to protect their children and family, though mostly living at the mercy of a neglecting or aggressive husband. They are dramatically engaging characters, but usually conform to a stereotypical image of motherhood, which can be understood in relation to nationalist and even religious selfabnegating symbols of maternity, who gain strength only through the role of mothers which defines them. In his Dublin Trilogy, he depicts mothers who are comparably devoted to their children. Mrs. Tancred and Juno Boyle whose sons die in the Irish Civil War, in contrast with the mother in Pearse's poem, lament their dead sons disregarding their sacrifice.

In contrast, Dancing at Lughnasa (1990) by Brian Friel, shows a darker dimension of the portrait of maternity represented in the characters of the Mundy sisters who struggle to survive the destitution of 1930s Donegal, and also here those women are reliant on offstage 
male characters. The play is set in a time when women, in Ireland and across continental Europe, were assigned domestic roles and nothing else.

Diane Stubbings argues that mothers who are present in many of twentieth-century Irish plays, with only a few exceptions, are "merely apparent" and enclosed by the male character(s). This representation of the social status of women persists in Irish theatre through most of the century. Patricia Kennedy, in Maternity in Ireland, affirms that mothers are "rendered invisible, or when visible . . . [are] seen one-dimensionally" (qtd Freeman 180). So the absent mother became a recurrent trope in Irish drama, though the absence is usually due to an early death. In Whistle in the Dark by Tom Murphy (196) the Irish family consists only from a father and sons, with no mother seen at home.

Brian Friel in his play Philadelphia, Here I Come! (1964) Replaces the real mother with a foster one represented by the housekeeper who became the center of care and affection for both the father and son. The Walworth Farce (2006) by Enda Walsh also focuses on a family with an absent mother, while the plays of Gary Mitchell talk about off-stage or ailing mothers who are physically absent.

Female dramatists have examined different features of motherhood, as indicated in Jozefina Komporaly's book Staging Motherhood, like the restrictions motherhood could place on identities and ambitions of women. Teresa Deevy's plays present characters that fear motherhood, and who themselves are motherless. In The King of Spain's Daughter (1935) Annie Kinsella can't bear to think of being a mother, while in Katie Roche (1936) the child of the title of the play has no mother. Anne Devlin dramatises mothers who are either dead
(Ourselves Alone (1985)) or unloving (After Easter (1994)), and they are usually interwoven in her characters' imagination with the figure of Mother Ireland.

On the other hand, Irish theatre is rich in plays celebrating the limitless support of mothers to their children, such as the plays of Christina Reid that feature a working class Protestant family that consists of three generations of women ( Tea in a China Cup (1983)) where the grandmother is depicted as a character offering the greatest level of motherly affection. And another family is seen in The Belle of the Belfast City (1989) where the senile grandmother unexpectedly shows wisdom and a sense of what really matters, defying sectarian and racist criminals defending her own daughters and granddaughters.

I. Modern and postmodern female Irish playwrights depicted the suffering mother as devastated and dominated by patriarchy. Jennifer Johnston, in her 1980 play The Nightingale and Not the Lark, presents Mamie, a heavy smoker and drinker, who takes little care of the performing hall she works in and less of herself. Stella Feehily, in O Go My Man (2006) introduces a forsaken wife and shallow girlfriend while her play Dreams of Violence (2009) "makes a strong case for politically committed women and the burdens placed on them," it is "a witty exploration of the dilemmas facing the militant working woman" (Billington, "Dreams of Violence").

II. Mary Trotter perceives Marina Carr's drama as a mixture of conflicting poles of "late twentieth century realism" combined with "Yeatsian fascination with the transcendent, liminality, spirituality, myth, and the occult" (168), that is why Christopher Murray 
recognises her as an "Avant garde" dramatist in contemporary Irish theatre (235).

III. When it comes to Marina Carr (1964- ), she gives a darker image of the postmodern woman and mother, as Lyn Gardner affirms:

Marina Carr's plays aren't a good advertisement for motherhood. An early work, The Mai, took its title from a figure in Irish mythology who destroys her young. The heroine of her bestknown work, Portia Coughlan, meanwhile, can empty a brandy bottle before 10am, dreams of mutilating her children and ends up drowning herself... her plays have frequently attracted controversy for their portraits of damaged women, bad mothers and unholy families. (The Guardian)

Fitzpatrick, likewise, sees that "Marina Carr's plays focus intently on motherhood to stage tense, unloving relationships between mothers and their daughters. Though physically present on stage her mother figures are often physically overwhelmed by child-bearing, or emotionally unavailable, and at times even hostile to their offspring." (2018).

Melissa Sihra makes a comparison between the plays of Lady Gregory and Carr, she highlights a rich creative lineage that challenges the patriarchal origins of modern Irish drama ("Marina Carr, descendant of Lady Gregory" 2019).

Victoria White, in her review of Carr's $B y$ the Bog of Cats, talks about her experience in watching a play that revolves around mothers and daughters, she sees in the play "women's rituals and psychological dynamics sketched for the first time on the Irish stage" (qt. Wilmer \& Dillon 140), the "wedding dresses and communion dresses and mother-daughter relationships" for her constituted "a whole symbolic system"(Ibid 141).

Carr shifts the focus of the traditional Irish "family memory play" (Trotter 165) from the conventional paternal relationships, that was the dominant theme the Irish theatre for a long time, to maternal ones. Carr challenges the male-centered Irish drama, to dramatise ordinary women's experience in a rural setting away from Irish national identity definitions and patriotism. Instead of dramatising women as the emblem of Ireland or, more specifically, the land, Carr portrays genuine, independent, sophisticated entities in their own right. Furthermore, she tends to deconstruct traditional notions of motherhood by displaying the conflict between the role of a mother on one hand and the role of a lover on the other hand (O'Dwyer 243).

Alan Bird affirms that through By the Bog of the Cats "Marina Carr has superbly reworked the Greek drama about the infanticidal Medea, transposing her from a mythical Greek heroine into the crude, rugged, wild Hester Swane - an Irish traveller living on the side of a bog" (2004).

Euripides' Greek tragedy Medea, a retelling of the myth of Jason and Medea, was produced in 431BC. Medea, a former princess of the barbarian kingdom of Colchis, believes that her position in the Greek world is threatened as her husband, Jason, betrays her and marries the princess of Corinth. She takes her vengeance by murdering Jason's new bride and her father as well as her own children, afterwards she escapes to start a new life in Athens.

Kerry Reid contends that even when $B y$ the Bog of Cats "has its roots in Euripides' 'Medea,' but its heart and soul is Irish" (2017). And Matt Wolf, in a review of the play considers 
it "a Celtic Medea in everything but name who speaks a language marinated in Yeats and Synge." (2004)

Carr's play begins at dawn with Hester Swane, a woman of forty, dragging the corpse of her childhood companion, a black swan to bury by her caravan. She is abandoned by her mother at the age of seven, and spends the rest of her life waiting, in vain, for her return. This maternal abandonment explains Hester actions which stem from her jealousy of Joseph, her brother whom she kills because he was closer to their mother, and also from her constant fear since everyone she loves eventually abandons her including Carthage Kilbride, the father of her daughter, who jilts her to marry a younger woman, she loses faith in love declaring that "love is only for fools and children" (BBOC 20). Just like her Greek counterpart Medea, Hester, rejected and misunderstood by her community, feels wronged and betrayed and decides to revenge by burning down the home she was forced to leave to be the house of the newlyweds, and sets fire to his livestock. She goes to the extreme to save her daughter, Josie, from the same fate she faced as a motherless child, she slaughter her then kill herself.

Bird considers the swan "as a type of surrogate mother to Hester, and so the trail of red blood left on the stage by Hester's dragging of the dead swan acts as a constant reminder of Hester's abandonment by her mother, when she was just a child." (2004) Yet the death of the black swan and meeting the menacing Ghost Fancier at the beginning of the play were portents of the disasters that about to follow and the impending death.

Carr employs the mythical story of Medea to historicise women's ongoing struggle to construct personal identity and gain a recognised position in a culture dominated by patriarchal values. In the male-centered theatre of the West, Medea has often been attributed the properties of an evil woman, the brute, the ferocious, the hysteric, the insane, or even the witch, only because her image has been drawn through the apprehensions of the male pysche. The patriarchal system has always gendered and rejected her reactions, her unmanageable rage, despise, and will for revenge in addition to her supernatural power, since they are not seen in agreement with the requirements of womanhood and motherhood. Marianne Hirsch sees that Medea, "step[s] out of a culturally circumscribed role which commands mothers to be caring and nurturing to others, even at the expense of themselves" (170). Carr opposes the social construction of identity in her play through a powerful account of a special mother-daughter bond. Carr aims to switch the focus of the Greek myth from stereotypical female sexual jealousy and evilness portrayed in the "malestream" dramatists to deeper layers of the female subconscious and the formation of her personality and identity in relation to a lost $\mathrm{m} /$ other. Thus, skillfully, Carr represents the myth of Medea from a feminine perspective.

Hester Swane is similar to Medea in being an outsider, a traveller. She lives in a caravan on the bog and struggls to construct her identity through a desperate search for a connection with her absent $\mathrm{m} /$ other. Carr intentionally adds ellipsis to the title of the play to refer to something incomplete, which could be a life journey that is still going on, or unfinished business (reconnecting to $\mathrm{m} /$ other). This fragmented relationship between the mother and the daughter is critical to understand the play since this abandonment by Big Josie Swane causes a split in the daughter's identity, and it is 
this abandonment also that is aggravated by her lover's abandonment and leads to a grave calamity at the end. However, unlike Medea, Hester murders her brother, Joseph not to help her lover, but to keep her mother for herself only; and she slaughters her daughter not for the sake of revenge on a betraying husband, but to spare her daughter the pain she had to endure in waiting endlessly for a mother whom she loves "more than anythin' in this cold white world"( BBOC 28) but will never return.

As mentioned earlier, depending on the Irish historical past, the woman in drama, is either eliminated from the stage, or idealized as a religious figure or a symbol of the nation (Mother Ireland), or of the land, and in accordance with this image she has been represented as an affectionate, kind, sacrificing, pure and loyal lover, wife and mother. In contrast to this idealised image, Carr represents women in her play to criticise the stereotypical image of women established by the majority of Irish male playwrights. She modifies the typical attributes of different roles assigned to women throughout history. Carr replaces the elderly, wise, woman who knows all, with the Catwoman, the Tiresias of the bog, who is wearing cats' fur, eating mice and licking milk out of a saucer, as a caricature or a bizarre parody or of the idealized Mother Ireland figure. Hester's absent mother Josie Swane, stands for all absent mothers who have been discarded in the father-centered drama. In addition, representing Hester as a raging, aggressive and obsessive woman subverts the conventional feminine roles of a wife and a mother as well as the image of femininity in the Irish drama. Hester doesn't have common feminine virtues of housewifing and mothering. Instead of taking care of her house and daughter, she spends her time roaming the bog and waiting for her mother. Hester discards her traditional role as a (common) wife and mother and instead she seeks a place in the society as an independent person. When she is denied that right, she acts like Medea, angrily and violently, and brings destruction. Culturally anger is not accepted as a feminine virtue, yet for a helpless oppressed woman, "to be angry is to claim a place, to assert a right to expression and to discourse, a right to intelligibility" as Hirsch asserts (169). Therefore, Hester, like Medea, is seeking a personal status, but the male figure stands in the way to prevent her from reaching it. Carr formulates female identity through the mother-daughter relationship, which is another deviance from the Irish dramatic tradition. Hester rage is triggered by her common-law husband's betrayal and humiliation, moreover, he, with the help of his new father-in-law, jeopardise her very female desire to be free in living on the Bog with her daughter. Meanwhile, Carr, by representing poverty-stricken rural women who are denied any access to the new financial, cultural, social, and educational opportunities made available by the economic boom and political stability of Ireland of the 1990s, she overtly challenges the mainstream representation of women on contemporary Irish stage.

Hester now is forced by Carthage, to leave the Bog which she holds dear, the place where her mother left her, and hopes one day that she would come back for her. She was born, lived, and is hoping to live there with her daughter until her mother return. "I watched her walk away from me across the Bog of Cats. And across the Bog of Cats I'll watch her return" (BBOC 33). 
When Carthage was poor and young, he was charmed by Hester, but when he became all wealthy and mature running the land and money of his in-laws, is trying to get rid of Hester by taking her house and throwing her out of the bog, and he even wants to deprive her of her own daughter, Josie. Hester confronts him saying: "The truth is you want to eradicate me, make out I never existed" (BBOC 41). Hester is exploited, humiliated, deprived of everything she holds dear, isolated and looked down upon as a witch, or a dissolute, and is considered as nothing. She tries to assert her identity one time through her connection with her mother, and another time through her relationship with Carthage, she declares: "Carthage Kilbride is mine for always or until I say he is no longer mine. I'm the one who chooses and discards, not him, and certainly not of yees. And I'm not runnin' with me tail between me legs just because certain people wants me out of their way" (BBOC 12). She refuses to be abandoned again by a loved one, so she reiterates that this time she would be the one who discards Carthage not the other way around.

Hester reacts to the male-dominance which has denied her voice/ identity, she challenges it through an outburst, an explosion, as Helen Cixous and Catherine Clement conclude that "Voice-cry. Agony - 'the spoken' word exploded, blown to bits by suffering and anger, demolishing discourse: this is how she has always been heard before, ever since the time when masculine society began to push her offstage, expulsing her, plundering her. Ever since Medea, ever since Electra" (qtd Aston 44).

The male dominance was challenged once by Hester's uninvited appearance in Carthage and Caroline's wedding wearing a white dress, and another time when she massacred all his animals, and set his house and sheds on fire. In fact, Carr, through the wedding scene attacks directly all traditional patriarchal institutions: she parodies the state, Church, marriage, and family and presents them as "false icons" (Cerquoni 186). Father Willow is a priest who "has his snuff on hand, pyjamas showing from under his shirt and trousers" (BBOC, 25), there are three women in wedding dresses and veils, one of them is the motherof the groom, Mrs. Kilbride, who states: "How was I supposed to know the bride'd be wearin' white as well". (Ibid 33) The language of the play also indicates the Freudian background of the characters, Mrs. Kilbride in a slip of the tongue says: "And that if Carthage will be as good a son to Caroline as he's been a husband to me then she'll have no complaints" (Ibid 35).

After being rejected and compelled to leave the bog by Carthage and his father-in-law, disparaged by Mrs Kilbride, and tyrannised by Xavier Cassidy, Hester turns into a helpless person, she has no hope in her mother's return, so she resorts to violence by committing arson in Carthage's farm. Against this background of hopelessness and violence, the only action left for her is committing suicide to remain connected to the bog which represents the $\mathrm{m} /$ other, especially after knowing from the ghost of her brother that her mother died a long time ago, so she finds in death a reunion with her long absent m/other. When she has that "death dance" with The Ghost Fancier who holds " the fishing knife, which ends plunged into [her] heart", her final words are: "Mam Mam - " (Ibid 45) and she dies. Her heart lies exposed "on top of her chest like some dark feathered bird" (Ibid) i.e. like her dear talismanic black swan. In this scene the natural and the mythic merge into one other. Bernadette 
Bourke finds in Hester's death a "renewal in a return to the great nurturing womb of nature, giver of life, death and continuity" (139). Yet, she takes little Josie with her to spare her a lifelong waiting for a mother who will never return, a fate worse than death, She comforts her saying:

Hester: It's alright, I'll take ya with me, I won't have ya as I was, waitin' a lifetime for somewan to return, because they don't, Josie, they don't. It's alright. Close your eyes. (Josie closes her eyes). Are they closed tight?

Josie: Yeah.

Hester cuts Josie's throat in one savage movement

(softly) Mam - Mam - (And Josie dies in Hester's arms).

Hester: (whispers) It's because ya wanted to come, Josie.

Begins to wail, a terrible animal wail. (BBOC 70)

Bourke believes that, "Carr has subverted the very notion of violence itself, by couching it in gentle, protective, motherly terms" (141). In an interview with Melissa Sihra, Carr argues that the closure of the play shows that Hester's final decision is brought by love rather than hatred (Sihra, "Stitching the Words" 1).

Hester finds in death a haven for herself and her daughter, where they can be emancipated from the social, economic, legal, and even political rules of the patriarchy. Carthage, who has been broken after her verbal outburst, and her burning of the animals and the house, is crumbled under the ferocity of her final act of self and identity affirmation of killing Josie then herself.
Carr's play, as a modern Irish tragedy created upon ideas and images inspired by Medea, has many similarities with Euripides' play; both plays react to the social and cultural atmosphere at the time, portray the hardships women face in their search for independence in a patriarchal society, and inspect the destructive effects of exile experienced by the "outsider". Carr wrote By the Bog of Cats during a period of great upheaval in Ireland, the same period that witnessed the legalization of divorce, the introduction of the euro, and increasing political activity with the approaching of the Good Friday Agreement, that is why the play is seen as portraying a dark image for a generation who were faced by fear and instability in the middle of tremendous social change. There is another link between Hester and Medea which is isolation. Medea is a barbarian princess who turned into a total stranger in Athens, while Hester is from a tinker family who does not belong in the settled community of the bog. Both women are excluded for being different, although the nature of their otherness is not something within their control. Hester confronts Xavier who is determined on scaring her away as he did with her mother. This confrontation reveals that Hester is strong but she is vulnerable at the same time, and she, like Medea, ultimately comes to accept her outsider status, deriving power from it. Yet her isolation is what restricts any possibility of a different ending. Because she is intimidated by the idea of being thrown out of her homeland and separated from her daughter, Hester has no other solution but to face her own feelings of abandonment and choose to save her daughter from a similar heartbreak. 
The setting of the play, a dreary white landscape of snow and ice of the bog is a deliberate choice by Carr. The gothic opening of the play shows Hester very closely connected to the place. Actually the bog constitutes the whole setting of the play, it represents the realm where the boundaries between the human and nonhuman, the real and the mythical, the living and the dead, the rational and the irrational, the natural and the unnatural, integrate with one another. The harsh, mysterious and gothic atmosphere of bogs resonates in the character of the heroine of the play, she is strongly related to the Bog which she considers an essential part of her identity: "I know every barrow and rivulet and bog hole of its nine square mile. I know where the best bog rosemary grows and the sweetest wild bog rue. I could lead yees around the Bog of Cats in me sleep. (BBOC, 15) M.K. Martinovich indicates that the Bog for Hester is "a source of spiritual fulfilment" where "she belongs to and feels at home in this world" (121). She states: "Ah, how can I lave the Bog of Cats, everythin' I'm connected to is here. I'd rather die" (BBOC 33), since it is the only link left to her mother, the bog is "characterized by loss and longing, yet it also represents her only site of connection and survival" (Cerquoni 183).

Hester perceives her survival through her connection to her mother, she declares "she's alive. I can smell her. She's comin' towards me. I know it. Why doesn't she come and be done with it! (BBOC 38) Christopher Murray believes that Hester's 'battle is for wholeness, for identity. But identity is now no simple matter but can even be a fiction" (qtd. in Sihra, "Stitching the Words" 3). Hester believes that her mother wrote songs specially for her and she refuses to let even her brother sing those songs which makes the whole play a sad love song of loss and abandonment. She hears the voice of her mother singing coming over the Bog. According to Cixous the $\mathrm{m} /$ other love stays alive as a voice: "the song, the first music of the voice of love, which every woman keeps alive" (qtd Çakirtaş 256) springs from the subconscious, from the past, which is now lost. It is the Voice of the Mother that when "raised loudly enough, threatens to shatter patriarchal tradition" (Ibid). Even though Hester's mother is physically absent from the stage, yet her voice is living on the Bog. Her songs "emanate a sense of freedom from all restrictions and limitations" (Ibid), therefore she was pushed to leave the bog; her exclusion from the stage indicates the exclusion of a different, aware, independent and a passionate woman/mother from the patriarchal order. Although she is not seen on the stage, her character is constructed by fragmented memories of her daughter and other characters, with different accounts from different character Big Josie's identity transforms into a fiction. In the eyes of Catwoman, she "was the greatest song stitcher ever to have passed through this place" (BBOC 31); but according to Xavier Cassidy, she would "go off for days with anywan who'd buy her a drink" (Ibid 37). However, Hester never perceives her as a flaw, a deficiency, an absence, but as "plenitude and fruitful" (Humm 80).

Bird argues that "Hester, like her beloved 'Bog of Cats', is both treacherous and bewitching." (2004) Anything can happen in the mischievousness of 'this auld bog, always shiftin' and changin' and coddin' the eye" (BBOC 25).

Boglands are areas of peat built up over hundreds and hundreds of years with a depth of several meters. A bog is formed of layers of vegetation and moss that break down very slowly. Like the complex history of Hester, the 
bog carries a deep dark history. She is strongly connected to the harsh landscape and can't imagine living anywhere else. This place connects her to the past in a bizarre way, bringing a link to a historical period in Ireland and resisting the quick change caused by technology and mechanisation. The power of Hester's "dark" ability and pagan beliefs is more understood because of the complex history of the bog. The bog as well holds dark secrets like the bodies of many victims are preserved for thousands of years in the bog with their compressed stories and memories that have been submerged. The ghost of Hester's brother, Joseph, comes to find her on the bog, the Ghost Fancier wanders freely where boundaries between the world of the dead and the world of the living are fallen in this mythical, mysterious place where past and present coexist in harmony.

Hester Swane was forced to turn into a dangerous woman yet she elicits compassion; she confesses, "I'm afraid of meself." (BBOC 36) she suffered for a long time from her mother abandonment and the rejection of her community. Carr herself sympathises with her says declaring: "I am on her side." (qtd Gardner 2004) What distinguishes Carr's drama is her informed compassion for the broken, the desperate, for those who outcry and rage as they hustle towards their ineluctable doom. Marina Carr modifies the rule that says: "Tragedy is so often the consequence of a fatal lack of selfknowledge" (Ibid) by endowing her characters with an excess of self-knowledge that proves to be fatal; "Their truth kills them. And they have always known it would."(Ibid)
Marina Carr adapted the Greek mythical story of Medea for the modern Irish stage. In $B y$ the Bog of Cats... Carr undermines many traditions of classical Greek and Irish drama in her presentation of mother figures who defy all masculine notions of the national and religious roles used to be attributed to women throughout history. The "Mother" in Carr's play does no longer represent "Mother Ireland" or the "Land", she is not a sacred, asexual, selfsacrificing passionate woman anymore. Instead of being confined in the roles of dutiful wives and mothers, Carr's females seek a confirmation of identity outside the institution of the family.

Women like Hester Swane are pushed to live on the margins of society, dispossessed of her home, roots, daughter, connection to her beloved bog and memories of her mother. She is cornered and hurt savagely to the extent she herself turns into a beast and kills her own daughter to spare her going through the same hardships she had to endure, then takes her own life.

Hester's search for her subjectivity and identity through a connection with her absent $\mathrm{m} /$ other barred by a patriarchal society consists of her common husband Carthage and his future father-in-law who take everything from her including her dignity.

Carr holds a mirror to reflect the female subconscious and allows women's voices to be heard. She gives voice to the oppressed, damaged, and silenced women who are prevented from participating in public life and restricted only in domestic roles.

She makes clear that cornered and maltreated women are liable to revolt to defend their rights and establish independent identities. 
Yet in her play the revolt went to an extreme and ended in a massacre.

The power of Carr's dramaturgy lies in her ability to give her characters many dimensions. Although Hester is basically a murderer who killed her brother, her daughter, and herself, she is still seen as a sympathetic character. She is an abandoned child who kept waiting for thirty three years for a mother who never came back. Rejected first by her own mother, then by the father of her daughter and society, she resorts to violence to revenge for her usurped dignity. Her aggressive actions are mere reactions to the way she has been treated, unjustly.

Marina Carr, as a feminist writer takes part in a new phase of modern Irish drama, a drama which is not father-based, not nationalist, not heroic, but humane and universal.

\section{Bibliography}

[1] Aston, Elaine. An Introduction to Feminism and Theatre. London: Routledge, 2003.

[2] Billington, Michael. "Review of By the Bog of Cats'. The Guardian. December 2, 2004). (Retrieved 20 May 2019).

[3] "Dreams of Violence" The Guardian. July 19, 2009.(Retrieved 15May 2019). https://www.theguardian.com/stage/2009/jul/19/dre ams-of-violence-review

[4] Bird, Alan "By the Bog of Cats". London Theatre. December 3,2004 (Retrieved 25 April 2019).https://www.londontheatre.co.uk/revie ws/by-the-bog-of-cats

[5] Bourke, Bernadette."Car's 2 cut-throats and gargiyles":

[6] Grotesque and Carnivalesque Elements in By the Bog of Cats...". The Theatre of Marina Carr: Before Rules Was Made. Ed. Cathy Leeney and Anna McMullan. Dublin: Carysfort Press, 2003.

[8] Cakirtas, Onder. Literature and Psychology: Writing, Trauma and the Self. Newcastle upon Tyne: Cambridge Scholars Publishing, 2019.

[9] Carr, Marina. By the bog of Cats. London: Faber\& Faber, 2004. Cerquoni, Enrica. " 'One Bog, Many Bogs': Theatrical Space, Visual Image and Meaning in Some Productions of Marina Carr's By the Bog of Cats". The Theatre of Marina Carr: Before Rules Was Made. Ed. Cathy Leeney and Anna McMullan. Dublin: Carysfort Press, 2003.

[11] Cixous, Helen and Catherine Clement. The Newly Born Woman. London: I.B. Tauris Publishers, 1996.

[12] Fitzpatrick, Lisa. "The powerful role of the mother in Irish Culture". $\quad$ RET. Ulster University, Aug 27, 2018. (Retrieved 28 April 2019) https://www.rte.ie/brainstorm/2018/0823/986996the-powerful-role-of-the-mother-in-irish-culture/
[13] Freeman, Sara. Theatre History Studies: 2016, Volume 35. Tuscaloosa: University of Alabama Press, 2016.

[14] Hirsch, Marianne. The Mother/Daughter Plot: Narrative, Psychoanalysis, Feminism. Bloomington and Indianapolis: Indiana University Press, 1989.

[15] Humm, Maggie. Practising Feminist Criticism: An Introduction. London: Prentice Hall/Harvester Wheatsheaf, 1995

[16] Gardner, Lyn "Death becomes her" The Guardian. November 29, 2004 (Retrieved 22May 2019). https://www.theguardian.com/stage/2004/nov/29/th eatre

[17] Martinovich, M.K. "The Mythical and the Macabre: The Study of Greeks and Ghosts in the Shaping of the American Premiere of By the Bog of Cats...". The Theatre of Marina Carr: Before Rules Was Made. Ed. Cathy Leeney and Anna McMullan. Dublin: Carysfort Press, 2003.

[18] Murrey, Christopher. Twentieth Century Irish Drama: Mirror Up to Nation. Manchester: Manchester UP, 1997.

[19] O'Dwyer, Riana."The Imagination of Women's Reality: Christina Reid and Marina Carr". Theatre Stuff: Critical Essays on Contemporary Irish Theatre. Ed. Eamonn Jordan. Dublin: Carysfort Press, 2000.

[20] Reid, Kerry. "'Bog of Cats': A Spurned Daughter Comes back in Angry Irish Take on 'Medea'". Chicago Tribune. February 21, 2017. (Retrieved 2 May 2019).https://www.chicagotribune.com/enterta inment/theater/ct-bog-of-cats-review-ent-0222 20170221-story.html

[21] Richman, David. Passionate Action: Yeats's Mastery of Drama. Newark: Univ. of Delaware Press, 2000.

[22] Ryschka, Birgit. Constructing and Deconstructing National Identity: Dramatic Discourse in Tom Murphy's "the Patriot Game" and Felix Mitterer's "in Der Löwengrube". Frankfurt am Main: Lang, 2008.

[23] Sihra, Melissa "Marina Carr, descendant of Lady Gregory" Apr 2, 2019. (Retrieved 16 May 2019).https://www.irishtimes.com/culture/boo $\mathrm{ks} /$ marina-carr-descendant-of-lady-gregory1.3846659_. "Stitching the Words: Marina Carr's By the Bof of Cats". Irish Theatre Forum 3.1 (Spring 1999): 1-10. http://www.ucd.ie/ irthfrm/issue52.htm

[24] Sternlicht, Sanford. A Reader's Guide to Modern Irish Drama. Syracuse, New York: Syracuse University Press, 1998.

[25] Synge, J M. The Complete Plays of John M. Synge: The Playboy of the Western World, Riders to the Sea, in the Shadow of the Glen, the Well of the Saints, the Tinker's Wedding, Deirdre of the Sorrows. London: Bloomsbury, 2001.

[26] Trotter, Mary. "Translating Women into Irish Theatre History" ACentury of Irish Drama: Widening the Stage. Ed. Stephen Watt et al. Bloomington and Indianapolis: Indiana UP, 2000.

[27] Wilmer, Stephen, and John Dillon. Rebel Women: Staging Ancient Greek Drama Today. London: Bloomsbury Publishing, 2014.

[28] Wolf, Matt. "By the Bog of Cats". Variety. December 7, 2004. (Retrieved 1 May 2019)https://variety.com/2004/legit/reviews/by -the-bog-of-cats-2-1200529166/ 
